\title{
Islam and State Ideology: Masyumi's Experience in Indonesian Politics
}

\author{
Warjio $^{1}$, Syaifuddin Lubis ${ }^{2}$, Yusniar Lubis ${ }^{3}$, Fajar Rezeki Ananda Lubis $^{4}$ \\ \{warjio1974@gmail.com¹,warjio@usu.ac.id², perubahanpolitik@gmail.com ${ }^{3}$ \} \\ Department of Political Science, Universitas Sumatera Utara (USU), Medan, Indonesia ${ }^{1}$ \\ Universitas PRIMA, Medan, Indonesia ${ }^{24}$ \\ Universitas Medan Area (UMA), Medan, Indonesia ${ }^{3}$
}

\begin{abstract}
Objective: The purpose of this paper is to investigate the history of Indonesian politics, the Indonesian Islamic party, Masyumi, has made efforts to propose Islam as the basis of the state at the beginning of an independent Indonesia. Methodology that used is history persfective based on history data.Result: Masjumi's struggle to make Islam the basis of the country was rejected by groups who supported Pancasila as the state ideology. Implication: This paper gives valuable reference to political elite parties to consider the adoption of policy based on history of partners and conflict management in the construction political institution in Indonesian politics.
\end{abstract}

Keywords: Islam, Islamic Political Party, Masyumi, State

\section{Introduction}

In Indonesia, in its political relations with the state, - especially in matters of state ideology, Islamic parties are always considered "sources of problems" in the process of political development. Indonesia's experience, during the administration under President Ir. Soekarno's political parties based on Islam were often seen as competing powers that could be a threat and had to be suspected [1][2]. For this reason, President Ir. Soekarno always tried to weaken and marginalize the role of these Islamic parties. As a result, leaders of Islamic parties failed to fight for Islam as a basis for the ideology and state religion in 1945 and in the late 1950s. In addition, they are also considered as an opposition group that will obstruct the process of political development in Indonesia. It can be said that all the time between 1945 and 1960 political Islam, which was characterized by the struggle for Islamic ideology as the basis of the state, was successfully paralyzed.

On the other hand, Islamic political party activists looked at the country suspiciously. They view the state as having implemented various policies to eliminate the importance of Islamic politics and at the same time support the idea of a secular political society. This suspicion stems from the ideology that differ between Islamic parties who fight for the ideology of Pancasila. It can be said that mutual suspicion between Islam and the state takes place in a country where the majority of the population is Muslim. This situation continued in several political periods, namely the revolutionary period of independence (1945-1949), the period of the political system of Parliamentary Democracy (1950-1959), Guided Democracy (1959-1965) and the New Order period (starting 1966). 
In this connection, the power of political Islam in Indonesia that plays a major role in the process of strengthening the identity of political Islam in the Indonesian political stage is the Masyumi Islamic party. During its existence in Indonesia, Masyumi was a party involved in the Old Order's rule under President Soekarno. Because of this position Masyumi also accompanied the basic process of Indonesian politics until at least the 1960s.

Masyumi saw his direct involvement in state power as a way to realize his goals. In this way, according to one Masyumi activist [3], the laws of God did not only come from the mouth of the ulama above the mosque pulpit but also out of government employees and became state law. This paper discusses the relations between Islamic parties and the state in Indonesia in the formulation of state ideology. The focus was on the Masyumi Islamic political parties between 1945-1969. In Indonesia, political relations between Islamic parties, which involve Masyumi and the state are marked by tensions that lead to conflict. From political practice, how does the state respond to demands made by Islamic parties when proposing Islam is the basis of the state? On the contrary, what do Islamic parties do when the demand is opposed by the state?

\section{Early Realtionship based on The Formulation of State of Ideology}

To answer that problem, I first uncovered the initial relations of the Masyumi and State relations based on the formulation of the State ideology. When Indonesian independence was achieved on August 17, 1945, there were fundamental issues that would determine the future of the Indonesian state. That issue is the basis (Weltanschauung) what will be used by the Indonesian people? In his time, this problem was not only difficult to solve but instead became a prolonged polemic of ideology, before finally a compromise decision was made. In fact, this polemic caused the Indonesian nation to split into two large organizations: on the one hand those who proposed that the Indonesian state be based on nationality without any special connection to religious ideology, while on the other they proposed Islam as the basis of the state. In fact, this is a continuation of the "ideological debate" that has emerged during the Indonesian era under Japanese rule.

As Indonesia is known before independence, under Japanese rule, Dokuritsu Zyunbi Tyoosakai (Indonesian Independence Preparatory Agency for Investigation, BPUPKI) was established on April 9, 1945, chaired by Dr. Rajiman Widyoningrat. The task of the BPUPKI is to prepare Indonesia's independence including the fields of state formation, institutionalization, national borders and state ideology which will be used if Indonesia is independent. Except for ideological issues, the meetings conducted by BPUPKI ran smoothly. In terms of determining what ideology to use, two conceptions are proposed. By an Islamic organization approached by Ki Bagus Hadikusumo, Kasman Singodimedjo, Mohammad Hassan proposed a conception that an Islamic ideology needs to be made as an ideology of the state, on the grounds that the majority of Indonesia's population is Muslim. Whereas other organizations, which are regarded by nationalists; Ir. Soekarno, Muhammad Hatta proposed the conception that the country's ideology must be "free of religion". In this reality, on June 1, 1945, Ir. Soekarno through his speech at BPUPKI had proposed a conception of the country's ideology with what he called Pancasila [4].

In the view of Ir. Soekarno, Pancasila was a reflection of Indonesia's sociohistorical heritage which he later explained with five moral principles. Except from Islamic organizations, this speech received an extraordinary reception. Submission of Pancasila by Ir. 
Soekarno was the beginning of an ideological conflict with Islam in the history of the making of the country's foundation in Indonesia. The BPUPKI meeting which brought together Islamic organizations with their Islamic ideological conceptions and nationalist organizations with the Pancasila ideology conception ultimately did not produce a decision. Finally, the Nine Committee was formed, consisting of nine members; from Islamic organizations, Abikusno Tjokrosujoso, Abdul Kahar Muzakir, Agus Salim and Wahid Hasyim, and nationalist organizations consisting of Ir. Soekarno (Chairperson) Muhammad Hatta, A.A. Maramis (Kristian) and Ahmad Subardjo.

Finally, through the Nine Committee, the results of political compromise regarding the country's ideological debate were formulated. The result of that political compromise was the so-called Jakarta Charter on June 22, 1945. In essence, both nationalists and Muslims accepted Pancasila. In this Jakarta Charter, Pancasila as the basis of state ideology has been accepted, but the principle of Godhead, which by Ir. Soekarno in his speech at BPUPKI was placed last, by the Nine Committee placed as the first precept followed by verse: with the obligation to carry out Islamic law for its adherents.

For Indonesian Muslims, this verse is very important because it is good for the implementation of Islamic sharia in an open institution in the future. This is one of the reasons why Islamic representatives in BPUPKI can compromise with nationalists. However, this situation did not last long. Because on August 18, 1945, one day after Indonesia's independence, at the insistence of a Christian minority organization in Eastern Indonesia, Muhammad Hatta and Islamic leaders held a meeting again. Christian minority organizations object to the verse, and if the verse is not removed, they will separate from Indonesian territory. As noted B.J. Boland, Muhammad Hatta reminded Islamic organizations that Indonesia, seen from the religion of its inhabitants, was not a homogeneous country [5]. Finally a compromise decision was made again with the result of the abolition of the verse. Ten years later, after the 1955 election under the Provisional Constitution (UUDS) of 1945, the return of Islam and the Pancasila bloated in the arena of the formation of the Indonesian state base. This is the end period for the victory of nationalist organizations.

\section{Ideological Conflict : Masyumi’s Struggle}

The process of the results of the 1955 elections gave rise to a prolonged ideological conflict. This is because the demands for the establishment of the constitution of the Indonesian state are increasingly felt. As is known, PPKI (Indonesian Independence Preparatory Committee) on August 18, 1945, one day after Indonesian independence was reached resulted in a mutual agreement, namely one state constitution, namely the 1945 Constitution (1945 Constitution). As stated by Ir. Soekarno, in his position as chairman of the PPKI, said that the constitution formulated by the PPKI was temporary. For existing political parties, as stated by Muhammad Natsir, from Masyumi, each party in the constituent council established after the election will draft a permanent constitution, and Masyumi will fight for the "content and nature" of Islam in the drafting of the laws. the constitution. Each political party has prepared its own formulation of what form or foundation to use in the permanent institutionalization. in this connection, Masyumi and other Islamic parties (NU, PSII) believe that Islam is the most suitable basis for or to shape state institutions. This is because the Islamic ideology and the state institutionalization model, as stated by Leonard Binder, are very important factors in determining the identity of an Islamic state [6]. 
In the Constituent Assembly, initially there were three drafts prepared to be submitted as a basis for the state. The three plans are: Islam, Pancasila, and Socio-Economy. At that time President Ir. Soekarno was more actively involved in political intervention. Pancasila presented by Soekarno as a substitute for the concept of an Islamic state. Previously, in 1953, Ir. Soekarno when giving a speech in Amungtai, Kalimantan, stated that if we establish a state based on Islam, then some regions whose inhabitants are not Muslim such as Maluku, Bali, Flores, Timor, Kei Islands, West Irian and Sulawesi will separate.

Response to the President's speech Ir. Soekarno clearly received a strong reaction from Islamic organizations. They considered that what was done by Ir. Soekarno had exceeded the limits of his authority, that the speech had spread the seeds of division and it showed the partiality of President Ir. Soekarno as head of state to organizations that opposed Islamic ideology. This fact is clear, Ir. Soekarno with his position as president, not only made use of his position to seek popular support for the ideology of Pancasila, but President Ir. Soekarno also appeared as a campaigner for supporters of the ideology of Pancasila [7]. Soekarno's speech was strongly opposed by Masyumi figures such as K.H. Muhammad Isa Anshary and Muhammad Natsir. Muhammad Natsir said [8]:

"Pancasila does not deserve to be the state ideology, because the precepts are all relative, both the precepts themselves and the relationship with one another. In contrast to Pancasila, Islam

has laws given to humans by God through revelation which provides an absolute measure to regulate human problems. "

Muhammad Natsir [8] mentioned that President Ir. Soekarno himself did not see Pancasila as a philosophy with deep roots, but only as a place for the integration and meeting of all the views of different organizations in Indonesia. Muhammad Natsir stated that as a pure concept, the precepts in Pancasila were not able to shape reality in actual situations; even if the basics apply, they will not be neutral anymore. The ambiguity of the Pancasila will not convince Muslims who already have a clear ideology to support Pancasila as a substitute for Islam. Going from Islam to Pancasila is like jumping from the earth into a vacuum.

In PNI it self, and also supporters of the ideology of Pancasila, what was done by President Ir. Soekarno was the right step towards his position as a president, leader of the revolution, who gave direction to the people. In their view the speech should be seen as an action to maintain the unity of Indonesia, to prevent things that could result in the development of politics in which the majority organization oppresses minority organizations and also to place these minority organizations in their proper place in the Republic of Indonesia, if this country based on the majority organization (Islam ) [9].

In an effort to fight for Islamic ideology, according to one Masyumi [3], there is a goal that needs to be fought by Masyumi, which he calls a maxima target and a minimum goal, which must be accompanied by a firm attitude. The maximum goal which is the ideal goal for Muslims. This demand is a formal and ideological Islamic state according to Islamic teachings, in accordance with the example of a country that was carried out in the time of the prophet and khulafaur rasyidin. A minimum goal is a target that can not be negotiable or reduced. For this we consider the Constitution (UUD) is not contrary to Islam, can also be used as a base to continue the struggle. From here we do the main business and ideals of Islamic ideology, namely:

1. Our country is a republic that is elected by the teachings of Islam and the conditions desired in Islam. The president must be a Muslim citizen.

2. Our country is a state of law and sovereignty is in the hands of the people. This is in accordance with Islam which embraces the ideology of "divine law"

3. Our country is an Islamic state 
4. The country is based on the Almighty God, where we have to fill on the basis of Islam

5. Our country recognizes basic rights

6. Our country recognizes the family economy

\section{Masyumi and The State in Responding to State Ideology}

For Masyumi, the struggle to determine and establish Islam as a state ideology, the existence of other ideologies such as communist ideology and nationalism ideology, in the development and competition of political parties, is a threat and considered contrary to the ideology of Islam itself.For Masyumi, their decision to propose Islam as the basis of the state, is a maximum goal. In a political context, there are at least a number of reasons that can be proposed why Masyumi is so eager to propose Islam as the basis of the state. Masyumi assumed that the issue of Pancasila as the basis of the state was a matter of interpretation. The reality is not only the secular nationalists, Christians, Catholics and Socialists, but the communists also ultimately support Pancasila. Also the Murba and Labor Party which initially proposed "Social Economy" as the basis of the state, instead later supported Pancasila. In addition, Masyumi figures want to fulfill their promises to their members and supporters in the election. As is known, in the 1955 elections, Masyumi had promised that they would fight for Islam as the basis of the state in the Constituent Assembly. The Syuro Masyumi Assembly has issued a fatwa that the people are obliged to choose a party that fights for Islam as the basis of the state. Clerical organizations entrust "mandate" to Islamic parties to fight for Islam as the basis of the state [10].

The historical fact of Indonesia has proven that both of these traditions have long influenced the social fabric of the Indonesian people in facing the patterns of the Indonesian national movement. Many scholars even believe that these two streams actually influence the political flow of the Indonesian national movement a lot.From this historical foundation of thought then emerged political demands (political claims) about who had the most role and determined the basis of Indonesia's struggle. Nationalists believe that the struggle for independence was started by the Boedi Oetomo organization which was founded on May 20, 1908. By nationalists, the founding of Boedi Oetomo was considered a very large and significant political organization in Indonesia [11].

From this root, other national movements emerged, such as: Indonesian National Party (PNI) 4 July 1927, Indonesian Party (Partaindo) April 1931 Greater Indonesia Party (Parindra) 26 December 1935. This movement was born as a reaction to colonialism and aspire Indonesian independence based on nationality. This is the purpose and fulcrum of these movements. When the Islamic school also believes that the establishment of the Sarekat Islam organization on October 16, 1905 as the starting point of the Indonesian national movement. According to KH. M. Isa Anshary, a Masyumi figure believes that Sarekat Islam is a continuation of history from hundreds of years of resistance carried out by Islamic fighters such as Prince Diponegoro, Imam Bonjol, Sultan Babullah in Ternate, Tengku Cik Di Tiro which is an embroidered of the Islamic struggle.

The assumptions of these two streams between nationalist and Islamic organizations towards the historical roots of Indonesia's political struggle ultimately confronted them again when the state's foundation was suggested by these two streams. The Islamic sect considers Indonesian independence not only to mean Indonesian independence, but also to the independence of Indonesian Muslims and also to the independence of Islam. In the early 
1940s the polemic between national and Islamic organizations about the idea of the state and Islam, transcended the problem of nationalism. Ir. Soekarno, as the most powerful representative of nationalist organizations and Muhammad Natsir, representing Islamic organizations was the most influential in voicing his thoughts.

Through the Pandji Islam magazine published in Medan, we can in fact conclude that Ir. Soekarno actually basically supported the separation between Islam and the state. He firmly opposes the formal relationship between Islam and the state, because this will create injustice against non-Islamic societies. In his article titled "I am not Dynamic" in the Pandji Islam magazine, Ir. Soekarno wrote [9]:

"So that reality shows us that the basis of religious and state unity for its population which is not $100 \%$ unanimous to all Islam, cannot coincide with the principle of democracy. For such a country, only two alternatives, only two are chosen: one of them, the unity of the state-religion, but the zonder of democracy; or democracy, but the state is separated from religion! The unity of a religious state, but disobeying democracy and playing a dictator, or loyal to democracy, but letting go of the foundation of religious and state unity. "

From what was explained by Ir. Soekarno above, it was clear he did not approve the establishment of religion in the state space. According to him, if religion is united in a state space then democracy will not emerge. Therefore the best way is to separate the two.

According to Muhammad Natsir [8], one of the Islamic leaders who most often voiced the aspirations of Muslims stated that the independence achieved by Indonesia was for Islamic independence, so that Islamic principles were implemented for the welfare and perfection of the Muslims and all of God's creations. Muhammad Natsir also asserted that "without Islam the Indonesian nationalism will not exist because Islam has first removed the" inferiority "attitude of diverse islands." With such a national view Muhammad Natsir insisted that the struggle of Muslims would not stop until here (independence), but will continue its struggle as long as the state has not been based and regulated according to the state structure of Islam. Continuing polemic between secular organizations that want to separate religion from the state and Islamic organizations who want the ideology of Islam to become the ideology of the Indonesian state, is seen as a political conflict.

According to Ahmad Suhelni [12] there are three reasons that caused the Islamic groups to oppose the ideas of Ir. Soekarno. The first reason, because Muslim leaders, especially those who launched criticism of Ir. Soekarno assumed that scientifically Soekarno had not yet mastered the problem of Islamic statehood. In their view Ir. Soekarno was a political figure who had just studied Islam and loved his religion. Besides that, Islam that was explored by Ir. Soekarno was not studied directly from books written by Islamic scholars, but from books written by orientalists. This can be understood considering that Ir. Soekarno did not understand Arabic.

The second reason, Ir. Soekarno and the Indonesian National Party (PNI) he led. Muslims doubt the loyalty and attachment of Ir. Soekarno in person towards the teachings of Islam. He is also considered to often be westernized, which does not reflect the personality of a Muslim. This conclusion was drawn because Ir. Soekarno tended to side with Western-educated organizations that were often anti-Islamic. This accusation is reinforced by the political reality in which Soekarno often debated with Islamic figures such as Haji Agus Salim, Muhammad Natsir Ahmad Hassan and others. At the same time Ir. Soekarno was considered not to want Islam to become a dominant form in the political arena in Indonesia.

The third reason, Islamic leaders such as Muhammad Natsir and Ahmad Hassan considered that the idea of separation of religion from the state proposed by Soekarno was a 
distortion of the history of Islam. Because in the history of Islam there is no known understanding of the separation of religion and state.

Pioneered by Masyumi, Islamic organizations put forward their ideas about Islam as the basis of the ideology of the Indonesian state. As many investigators note, between 1955-1959 the agenda of the basic debate of state ideology in the Constituent Assembly took place "hotly". However, for Masyumi and other Islamic parties, it is not easy to propose Islam as the state ideology. As is known, the results of the 1955 election decision did not produce a "majority victory" both for political parties and organizations. By only controlling 44.36 percent of seats in the parliament of Islamic organizations, Islamic organizations find it difficult to push the Islamic idea as the basis of the state or not. On the other hand, the support organization for Pancasila, despite having a greater number of votes, 286 votes (55.64 percent), did not meet the majority vote of $2 / 3$ (66.7 percent). So in theory, without compromise, both Islam and Pancasila, neither can be used as a basis for the state. As is known, the debate to establish Islam as the ideology of the Indonesian state as suggested by Masyumi was severely challenged by nationalist organizations, especially President Ir. Soekarno, who proposed Pancasila as the state ideology.

As is known, the debate to establish Islam as the ideology of the Indonesian state as suggested by Masyumi was severely challenged by nationalist organizations, especially President Ir. Soekarno, who proposed Pancasila as the state ideology. Because of the "heat" of this debate, President Soekarno dissolved the Constituent Assembly in July 1959. This dissolution was actually for President Ir. Soekarno in order to create a new political order, namely Guided Democracy (1959-1965).

Masyumi as a large Islamic party, is also steadfast and consistent in fighting for the aspirations of the people. What happened in the parliamentary debate to draft definitive laws proves that. With Masyumi figures fighting for the foundations of a state based on Islam. Opposition occurred with nationalists who wanted Pancasila as the basis of the state and with groups from the communist Indonesian Communist Party (PKI). For Masyumi, the issue of Islamic ideology in the context of the state, and as a basis for the state is very important and mustahak in the socio-political position of the Indonesian people where the majority are Muslim. Said Muhammad Natsir on the occasion [8]:

"In Indonesia the ideology of life that drives people is religion. I have stated the religion of its general characteristics. Naturally, the basis of our country is based on religion, not a series of ideas that are considered generally accepted, as Pancasila. Pancasila is not trusted by a religion. Even if there is a formulation in the precepts of the Godhead, the source, the background is secular, he is diniyah, without religion. My obligation and that of my friends from the Masjumi faction is to present before the honorable plenary session, our stance in a broader and deeper manner than what we have said in the constituent preparation commission and committee. That is our will as we all know that our Republic of Indonesia is based on Islam, a democracy based on Islam".

Masjumi proposed Islam as the basis of the canyon as was the reason stated by Muhammad Natsir. He said again [8]:

"I conclude, not solely because Muslims are the largest group among the people of Indonesia as a whole, we propose Islam as the basis of our country. However, it is based on our belief that Islamic teachings on state administration and living societies have perfect characteristics for the life of the state and society and can guarantee diversity life for mutual respect between various groups within the state. Islam is a religion. A religion that lives in a large part of the Indonesian people. Not only that, Islam is an ideology. Islam is not merely a religion in the sense of the relationship between humans and God. Islam contains two elements. The element that contains the relationship between humans and God and the element of human relations with fellow 
creatures. The element of worship and muamallah. This second element, the muamallah element includes the lives of individuals, family and state life. In dealing with matters of state such as the constitution of the state, by itself we are mainly dealing with Islamic teachings stored in the second element, namely the muamallah element.

With the submission of Islam as the basis of this Indonesian state by Muhammad Natsir [8], the direction of political ideology became clearer as Masyumi wanted. Muhammad Natsir's reasons for proposing Islam as the basis of the state as above are due to several reasons. First, the existence of sociological facts, namely the community in Indonesia becomes the majority of musulim. Second, there is a normative factor that shows that before Pancasila was born, Muslims in Indonesia had made Islam and practiced Islam in their daily lives.

With another understanding, Muslims in Indonesia already know that as a religion, Islam is also their view of life. Third, there is a very strong commitment about Islam to Muhammad Natsir. This is proven by his statement about Islam as a guide in the life of the state and society. At the same time the Pancasila-supporting organizations rejected the idea of Islam as the basis of the state based on the possibility of its application. This is based on the reality of heterogeneous socially religious Indonesian society. Therefore, the Pancasila support group doubts that Islam can act as a worldview of political ideology for all Indonesians. This doubt (and concern) is clearly illustrated by Arnold Mononutu's statement, from the Christian PNI (Dasar Negara Republik Indonesia Dalam Konstituate, 1945):

"From the ideology of Pancasila to the state of Indonesia based on Islam for Christians is like: jumping from a quiet and peaceful earth to practice his religion as a human being of Indonesia, to the vacuum, not having air."

Arnold Mononutu's statement is in line with the statement of Sutan Takdir Alisyabana, who is also a supporter of Pancasila. He expressed doubts about the role of religion, which he saw failed in dealing with the problem of statehood. He said:

"In the midst of the differences and contradictions of religions that appear to him every day around him, the cases that arise in his heart are something natural, which must be contemplated by each religion with a case of awareness and understanding, if no one wants to lose followers. By simply blaming religious secularism there is no advantage; especially in a country where people are still lacking in Lithuania, religion will only benefit if it dares to dig deeper into its own base of secularism".

In the meantime, PKI figures such as Aidit, Sakirman and Njoto interpreted God in Pancasila as religious freedom. PKI, said the figures, looked at the existence of religions in Indonesia as a reality. Such interpretation is in accordance with the basics of Marxism and Leninism. Understanding religious freedom in the PKI's view also means freedom of not having a religion. PKI figures also added in their belief that religion was a personal human problem. Thus the state cannot force its people to embrace religion, or conversely force them not to have a religion. As for the secular nationalist organization, as stated by Soewirjo, the General Chairman of the PNI, expressed his support that because religion is very sacred and noble, we object to religion being used as the basis of the state (Dasar Negara di Konstituante. 1945).

In this condition, when the Islamic organization led by Masyumi insisted on proposing Islam as the basis of the state. When the secular-communist nationalist organization insisted with the Pancasila reserve, as revealed by Endang Syaifuddin Anshary, Wilopo, Chair of the Constituent Assembly, who was also a PNI leader, stated the need to fulfill the path of compromise. The processing of these types of ideologies is not possible to produce other results from compromise. In this connection, Wongsonegoro, Chair of the Greater Indonesia Party (Parindra), proposed the establishment of a special committee for a compromise 
administrator, consisting of ten members representing five from Islamic organizations and five from organizations supporting Pancasila.

\section{Conclusion}

Masyumi's desire to make Islam the basis of the country after Indonesia's independence was not as easy as imagined. The struggle to establish Islam as a state has not only been challenged but has also marginalized the power controlled by President Sukarno. President Sukarno was decisive in the end how Masyumi's struggle to make Islam the basis of the state and then marginalized because ultimately the Pancasila was established as the state ideology

\section{Acknowledgement}

On this occasion I have to say thousands of thanks to Dr. Arifin Omar, - lecturer at Universitas Sains Malaysia (USM), Penang, Malaysia at the time for his input and criticism so that this research could be completed.

\section{References}

[1] H. S. Benda, The Cresent and The Rising sun: Indonesian Islam under The Japanese Occuption. The Hague and Bandung: W. van Hove, 1960.

[2] H. Fedespiel, Persatuan Islam: Islamic Reform in Twentieth Century Indonesia, Ithaca: Modern Indonesian Project. South East Asia Program: Cornell University, 1970.

[3] Z. A. Ahmad, Konstitusi Yang Kita Ingini. dalam Suara Masyumi, 1955.

[4] A. K. Pringgodigdo, Sejarah Pergerakan Rakyat Indonesia. Jakarta: Dian Rakyat, 1967.

[5] B. J. Boland, The Stuggle of Islam in Modern Indonesia. The Hague: Martinus Nijhoff, 1971.

[6] Y. I. Mahendra, Modernisme dan Fundamentalisme dalam Politik Islam: Perbandingan Partai Masyumi (Indonesia) dan Partai Jamiat Al-Islami (Pakistan). Jakarta: Penerbit Paramadina, 1999.

[7] H. Feith, Soekarno-Militer dalam Demokrasi Terpimpin. Jakarta: Pustaka Sinar Harapan, 1995.

[8] M. Natsir, Islam Sebagai Dasar Negara. Jakarta, 2000.

[9] Soekarno, Di Bawah Bendera Revolusi. Jakarta: Panitia Penerbitan Dibawah Bendera Revolusi, 1964.

[10] Panitia Buku Peringatan Muhammad Natsir/Muhammad Roem, Mohammad Natsir: 80 Tahun Kenang-Kenangan dan Perjuangan. Jakarta: Pustaka Antara, 1978.

[11] G. M. Kahin, Nationalism and Revolution in Indonesia, Ithaca. New York: Cornell University Press, 1966.

[12] A. Suhelni, Polemik Negara Islam : Soekarno Versus Natsir. Jakarta: Penerbit Teraju, 2002. 